\title{
DCAF5 wt Allele
}

National Cancer Institute

\section{Source}

National Cancer Institute. DCAF5 wt Allele. NCI Thesaurus. Code C54544.

Human DCAF5 wild type allele is located within 14q24.1 and is approximately $102 \mathrm{~kb}$ in length. This allele, which encodes DDB1- and CUL4-associated factor 5 protein, is involved in the modulation of protein-protein interactions. 